\title{
Air Pollution and Economic Growth in MENA Countries: Testing EKC Hypothesis
}

\author{
Rami Al-Rawashdeh ${ }^{1}$, Aiman Q. Jaradat ${ }^{1}$, Mohammad Al-Shboul ${ }^{2}$ \\ ${ }^{I}$ College of Engineering, Al-Hussein Bin Talal University, Ma'an, Jordan \\ ${ }^{2}$ Department of Finance and Economics, College of Business Administration, University of Sharjah, UAE \\ Corresponding author: \\ R. Al-Rawashdeh, College of Engineering, Al-Hussein Bin Talal University, P.O. Box 20, Ma'an, Jordan \\ E-mail: r_rawash@yahoo.com.au
}

\begin{abstract}
The Environmental Kuznets Curve (EKC) hypothesis is one of the models describing the relationship between economic growth and environmental quality. The purpose of this study is to investigate the relationship between economic growth and the two environmental indicators $\left(\mathrm{SO}_{2}\right.$ emissions, $\mathrm{CO}_{2}$ emissions) in 22 Middle East and North Africa (MENA) countries. Based on a country level analysis and by using time series data, the study revealed that there is an evidence for $\mathrm{SO}_{2-}$ EKC for Algeria, Tunisia, Yemen, Morocco, Turkey and Libya. Our findings for $\mathrm{CO}_{2}$ emissions also support an inverted U-shape pattern associated with the EKC hypothesis for Tunisia, Morocco, Turkey and Jordan. The results also showed that MENA region as a whole did not show EKC for $\mathrm{SO}_{2}$ emissions and $\mathrm{CO}_{2}$ emissions. Stricter policy measures and higher demands for the adoption of best environmental practices are required in order to generate an inverted U shaped curve relationship between GDP per capita and environmental degradation.
\end{abstract}

Key words: Kuznets curve, MENA, economic growth, pollution, environment.

\section{Introduction}

The Middle East and North Africa (MENA) is a region rich in diverse natural resources. Several international organisations include different countries in their definition of MENA, but the main consensus seems to favour around 22 countries, which are Algeria, Bahrain, Djibouti, Egypt, Iran, Iraq, Israel, Jordan, Kuwait, Lebanon, Libya, Mauritania, Morocco, Oman, Qatar, Saudi Arabia, Sudan, Syria, Tunisia, Turkey, the United Arab Emirates and Yemen (International Monetary Fund (IMF), 2011; African Development Bank, 2013). Mauritania, Sudan and Turkey are not part of the MENA region in the World Bank's classification of countries; however, other institutions like the African Development Bank and the IMF sometimes include them in the list of MENA countries since they are geographically close to the region. The region has a characteristically harsh climate and limited ground water and rainfall. Yet it is rich in a wide range of natural resources. It contains important crude oil and gas reserves, numerous non- oil fuel, mineral and non-mineral resources, and some very productive pockets of agriculture. According to British Petroleum (2014), in 2013 MENA countries had $48 \%$ of the total world oil reserves accounting for $36 \%$ of the total world oil production and $43 \%$ of natural gas reserves representing around $17 \%$ of the total world production. The US Geological Survey (2013) estimates that the region contains about $85 \%$ and $70 \%$ of the total world reserves of phosphate and bromine producing around $32 \%$ and $74 \%$ of the total world production of phosphate and bromine, respectively. Additionally, the region accounts for $25 \%, 17 \%, 13 \%$, and $12 \%$ of the total world production of feldspar, arsenic, sulphur and gypsum, respectively.

The discovery of oil and gas and the realisation of their potential importance for meeting the world energy needs not only increased the strategic significance of several MENA countries, but also helped to integrate their economies into the global 
approach. During the $20^{\text {th }}$ century, the socioeconomic and political transformations of MENA countries and their relationship to major powers were influenced by the international political economy of oil and gas sector on the one hand, and by the impact of its development on individual Arab economies on the other hand.

Despite the fundamental role of oil and gas production as an engine of economic development, it is considered as the main contributor for global warming and climatic changes and one of the major sources of air emissions, particularly $\mathrm{CO}_{2}$ and $\mathrm{SO}_{2}$ pollutants.

Although the region contributes to a large fraction of the world's oil production, it only produces, through its own energy consumption, around $5 \%$ of global $\mathrm{CO}_{2}$ emissions. However, based on per capita $\mathrm{CO}_{2}$ emissions, six Middle Eastern countries ranked among the top 20 emitting nations in 2011 including the United Arab Emirates (4), Qatar (5), Kuwait (8), Bahrain (10), Saudi Arabia (13) and Oman (17) where numbers in parentheses account for global ranking (Energy Information Administration, 2014). The comparative position of MENA region with other regions in the world in terms per capita emissions of $\mathrm{CO}_{2}$ associated with energy consumption in 2011 is presented in Figure 1. The region is ranked second after North America and recorded 9.0 metric tons of $\mathrm{CO}_{2}$ per person, which was higher than the average value in the world (4.6) and higher than that in Europe (7.1), Asia (3.7) and Africa (1.1).

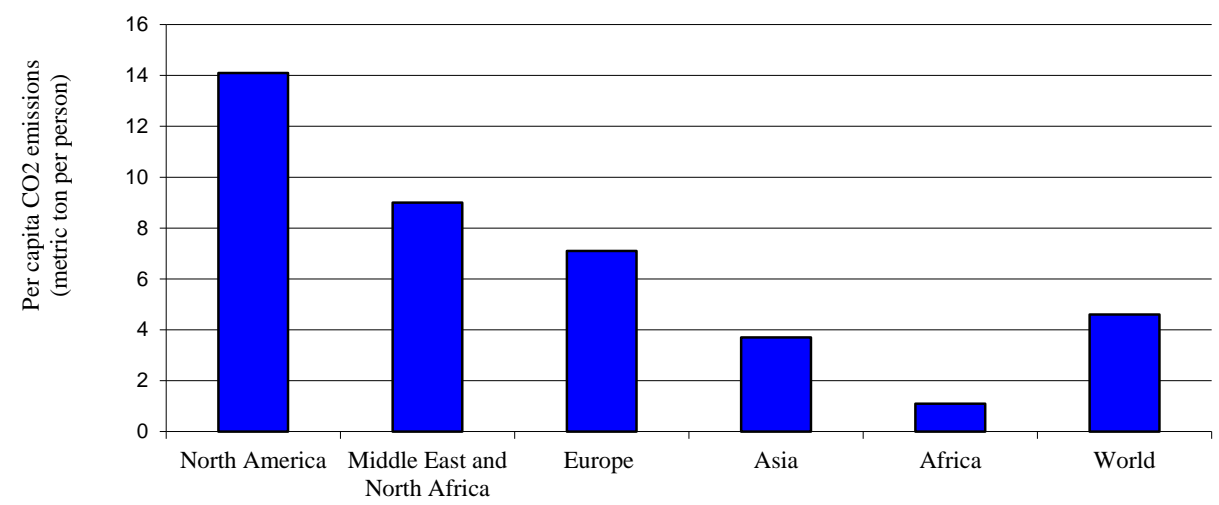

Figure 1. Per capita $\mathrm{CO}_{2}$ emissions from the consumption of energy in 2011 (Source: Energy Information Administration (EIA), 2014).

The average economic cost of environmental damage in MENA in 2013 was $4.3 \%$ of gross domestic product (GDP). According to the World Bank (2014), this cost varies from $2.7 \%$ of GDP in Tunisia to as high as $7.1 \%$ of GDP in Iran. This high cost of environmental degradation spills into public finances, household budgets, the competitiveness of the economy, and inter-generational equity. At current rates of resource exploitation and associated environmental degradation, many of the existing resources will not be available in the future.

The relationship between environmental quality and economic growth is puzzling. According to the Environmental Kuznets Curve (EKC) hypothesis, as income increases emissions increase as well until some threshold level of income is reached after which emissions begin to decline (Panayotou, 1993). Economic growth will trigger a composition shift of economic activity away from heavy manufacturing to services, and it may also generate environmental benefits through the development and adoption of new technology, i.e. cleaner production and improved energy efficiency.

With regard to emerging economies, most EKC studies focus on Asian and Latin America countries (Kraft and Kraft, 1978; Soytas et al., 2007; Ang, 2007; Soytas and Sari, 2009). A recent literature survey presented by Arouri et al. (2012a) confirmed that less attention has been given to smaller emerging countries, especially in the Middle East and North Africa region (MENA).
Djoundrian (2011) conducted a comparative study across the Arab world to determine whether variations exist in environmental performance. Using various indicators of performance, including the 2010 environmental performance index and the total number of international environmental agreements signed, ratified or accessed by individual governments, he concluded that the Arab world is at par with the developing world with its environmental performance. His results showed that economic wellbeing determines environmental performance, thus providing evidence to support the EKC hypothesis.

Arguing on the basis of the EKC hypothesis and using panel data on the income-emission-democracy nexus, Farzanegan and Markwardt (2012) showed evidence that improvements in the democratic development of the MENA countries help to mitigate environmental problems. Their results clearly showed that the quality of democratic institutions has a greater influence on local environmental problems than on global environmental issues in the MENA region.

Gurluk (2009) examined the relationships between biological oxygen demand (BOD) and per capita gross domestic products (GDP) in European, Euro-Asian and African-Mediterranean countries, which have different economic and institutional backgrounds. A modified human development index (MHDI) was applied to measure the effects of human development in different countries. In his results, apart from France, all countries follow increasing 
logarithmic or inverse-logarithmic curves that keep on the industrial pollution path.

Fodha and Zaghdoud (2010) investigated the relationship between economic growth and pollutant emissions for a small and open developing country, Tunisia, during the period 1961-2004. The investigation is made on the basis of the Environmental Kuznets Curve hypothesis, using time series data and cointegration analysis. Carbon dioxide $\left(\mathrm{CO}_{2}\right)$ and sulphur dioxide $\left(\mathrm{SO}_{2}\right)$ were used as the environmental indicators, and GDP as the economic indicator. Their results showed that there is a long-run cointegrating relationship between the per capita emissions of two pollutants and the per capita GDP. An inverted $U$ relationship between $\mathrm{SO}_{2}$ emissions and GDP has been found. However, a monotonically increasing relationship with GDP is found more appropriate for $\mathrm{CO}_{2}$ emissions.

Jaunky (2010) tested the EKC hypothesis for 36 high-income countries (including three MENA countries: Bahrain, Oman and the UAE) over the period 1980-2005. His empirical analysis based on individual countries suggested that for Oman (and for other 6 non-MENA countries) as well as for the whole panel $\mathrm{CO}_{2}$ emissions fell as income rose in the long run. Narayan et al. (2010) tested the Environmental Kuznets Curve (EKC) hypothesis for 43 developing countries for the period from 1980 to 2004. They found that for the Middle Eastern panel, $\mathrm{CO}_{2}$ emissions have fallen with a rise in income. In a recent paper, Arouri et al. (2012a) tried to verify the existence of EKC in 12 MENA countries over the period from 1981 to 2005 . Their results provided poor evidence in support of the EKC hypothesis for MENA. Al-Mulali (2011) used a panel model for 12 MENA countries during the period 1980-2009. Based on cointegration test results, he found that $\mathrm{CO}_{2}$ emissions and oil consumption have a long-run relationship with economic growth.

While most previous studies conducted on MENA region focused on a selected sample of MENA countries, our approach is to examine whether or not the relationship between economic growth and $\mathrm{CO}_{2}$ and $\mathrm{SO}_{2}$ emissions is still valid for all of the 22 MENA countries in the region based on a country level analysis from 1960 to 2010. Our study will use $\mathrm{EKC}$ as a tool in order to reveal and highlight which of the 22 MENA countries requires a comprehensive environmental policy in order to alleviate the damage to the environment.

The remaining part of the paper is divided into four sections, beginning with Section 2 - which briefly discusses the methodology used on the study. Section 3 describes the data, using different sets of statistical tests, and discusses the empirical results for the two environmental indicators, while Section 4 concludes the paper.

\section{Methods}

From previous empirical studies on the relationship between economic growth and environmental quality, the basic EKC equation can be specified in quadratic equation as follows:

$$
\begin{aligned}
\operatorname{Ln}(E D)_{i, t}=\beta_{0} & +\beta_{1}(P C G D P)_{i, t} \\
& +\beta_{1}(P C G D P)_{i, t}^{2}+\varepsilon_{i, t}
\end{aligned}
$$

where $E D$ is the indicator of environmental degradation, $P C G D P$ is the per capita GDP (in 2005 constant US dollars), $\varepsilon_{i}$ is the disturbance term with zero mean and finite variance, $i$ and $t$ refer to countries and time periods.

In order for the EKC hypothesis to hold, $\beta_{1}$ has to be positive, and $\beta_{2}$ has to be negative and both must be statistically significant (Orubu and Omotor, 2011). If, for example, in equation (1) $\beta_{1}<0$ and is statistically significant, but $\beta_{2}$ is not statistically significant, then the EKC is unconventional and is a negatively sloped straight line. On the other hand, if $\beta_{1}>0$ and is statistically significant, while $\beta_{2}$ is not statistically significant, then the environmental indicator may worsen as per capita income increases and the EKC is a positively sloped straight line.

The turning points show the level of income above which pollution declines, and it is after this point that higher growth will accompany lower environmental degradation. The estimated turning points depend on the kind of pollutant the researchers study (Alstine and Neumayer, 2010). While higher turning point may indicate that more environmental degradation has happened in the past, Oruba and Omotor (2011) reported that a low turning point could appear earlier if human activities are environmentally friendly and sustainable. Also, low turning points may indicate that countries do not need to wait long for high threshold per capita income to appreciate cleaner environment. The turning point, the level of income where emissions or concentrations are at a maximum, can be found using the following equation:

$$
t=\exp \left[\frac{-\beta_{1}}{2 \beta_{2}}\right]
$$

where $t$ is the turning point and an EKC may be established within the context of the conventional quadratic specification.

In our empirical analysis, we have used individual country time series data for 22 MENA countries to establish EKCs analysis by using per capita gross domestic product (GDP) at constant dollar (2005) as the economic indicator, and $\mathrm{CO}_{2}$ emissions and $\mathrm{SO}_{2}$ emissions as environmental indicators. All countries' data are sourced from the World Bank data series (2014).

\section{Empirical results and discussion}

\subsection{Testing for unit roots and cointegration}

In this section, we show the relationship between GDP per capita and each of the two variables of 
interest (i.e. $\mathrm{CO}_{2}, \mathrm{SO}_{2}$ ) for selected countries in our sample and for all countries as a panel. This is achieved by testing for cointegration among the three variables using Johansen's methodology (Johansen, 1988). The properties of variables need to avoid the possibility of spurious regressions. Therefore, in order to do so, we have to assess the stationarity of the variables employed.

In order to run a regression analysis, all variables used in the analysis have to be stationary. A stationary time series is one whose statistical properties such as mean, variance and autocorrelation are all constant over time. To test for stationarity, we employ two different unit root tests, which are the Augmented Dickey-Fuller (ADF) (Dickey and Fuller, 1981) and the Kwiatkowski-Phillips-Schmidt-Shin (KPSS) unit root tests (Kwiatkowski et al., 1992). If the residuals are in fact stationary, then this means that the variables are cointegrated presenting a long run relationship. But if they are not stationary, then we have to transform them to become stationary by differencing the data once or more.

A test for cointegration has also to be performed in order to check for a long run relationship among the selected variables in the model. The diagnostic testing results for stationarity are reported in Table 1. This table presents the summary of the unit root testing results for the three variables used in our study: GDP per capita, $\mathrm{CO}_{2}$ and $\mathrm{SO}_{2}$ for each individual country and for all countries as a panel.

Table 1. Unit root testing for $\mathrm{CO}_{2}, \mathrm{GDP}$ per capita and $\mathrm{SO}_{2}$ variables.

\begin{tabular}{|c|c|c|c|c|c|c|}
\hline \multirow{3}{*}{ Country } & \multicolumn{6}{|c|}{ ADF } \\
\hline & \multicolumn{3}{|c|}{ Level data } & \multicolumn{3}{|c|}{$1^{\text {st }}$ difference } \\
\hline & $\mathrm{CO}_{2}$ & GDP per capita & $\mathrm{SO}_{2}$ & $\mathrm{CO}_{2}$ & GDP per capita & $\mathrm{SO}_{2}$ \\
\hline Algeria & -1.24 & -2.35 & -0.93 & $-10.7^{a}$ & $-4.41^{\mathrm{a}}$ & $-6.29^{a}$ \\
\hline Egypt & -0.79 & -0.90 & -1.77 & $-9.76^{a}$ & $-4.17^{a}$ & $-5.61^{a}$ \\
\hline Iran & -1.41 & -2.43 & -1.80 & $-7.02^{a}$ & $-3.44^{a}$ & $-5.72^{a}$ \\
\hline Jordan & -1.47 & -1.81 & -1.63 & $-10.4^{a}$ & $-3.87^{a}$ & $-5.76^{a}$ \\
\hline Kuwait & -1.46 & -1.25 & -1.94 & $-9.35^{a}$ & $-7.69^{a}$ & $-6.19^{a}$ \\
\hline Morocco & -1.03 & -1.97 & -2.43 & $-7.14^{\mathrm{a}}$ & $-11.2^{a}$ & $-6.72^{a}$ \\
\hline Oman & -1.13 & -1.88 & -1.60 & $-8.81^{a}$ & $-5.14^{\mathrm{a}}$ & $-5.18^{a}$ \\
\hline Qatar & -2.20 & -1.65 & -0.64 & $-5.89^{a}$ & $-6.83^{a}$ & $-6.71^{a}$ \\
\hline Turkey & -1.23 & -1.25 & -2.17 & $-7.61^{a}$ & $-7.17^{a}$ & $-6.96^{a}$ \\
\hline The UAE & -1.89 & -1.34 & -2.27 & $-7.97^{\mathrm{a}}$ & $-4.84^{a}$ & $-5.78^{a}$ \\
\hline All countries & -2.21 & -2.07 & -2.20 & $-7.15^{a}$ & $-6.77^{a}$ & $-6.77^{a}$ \\
\hline \multirow{3}{*}{ Country } & \multicolumn{6}{|c|}{ KPSS } \\
\hline & \multicolumn{3}{|c|}{ Level data } & \multicolumn{3}{|c|}{$1^{\text {st }}$ difference } \\
\hline & $\mathrm{CO}_{2}$ & GDP per capita & $\mathrm{SO}_{2}$ & $\mathrm{CO}_{2}$ & GDP per capita & $\mathrm{SO}_{2}$ \\
\hline Algeria & 0.12 & $0.15^{\mathrm{a}}$ & $0.23^{\mathrm{a}}$ & 0.11 & 0.13 & 0.11 \\
\hline Egypt & $0.24^{\mathrm{a}}$ & $0.17^{\mathrm{a}}$ & 0.10 & 0.09 & 0.08 & 0.11 \\
\hline Iran & $0.21^{\mathrm{a}}$ & 0.11 & 0.08 & 0.16 & 0.14 & 0.06 \\
\hline Jordan & $0.24^{\mathrm{a}}$ & 0.10 & $0.19^{a}$ & 0.04 & 0.15 & $0.17^{\mathrm{a}}$ \\
\hline Kuwait & $0.16^{\mathrm{a}}$ & $0.15^{\mathrm{a}}$ & 0.07 & 0.10 & 0.06 & 0.10 \\
\hline Morocco & $0.24^{\mathrm{a}}$ & 0.14 & $0.20^{\mathrm{a}}$ & 0.04 & 0.12 & $0.15^{\mathrm{a}}$ \\
\hline Oman & $0.19^{a}$ & 0.09 & 0.15 & $0.50^{\mathrm{a}}$ & 0.09 & 0.14 \\
\hline Qatar & 0.11 & $0.15^{\mathrm{a}}$ & $0.22^{\mathrm{a}}$ & 0.09 & 0.14 & 0.13 \\
\hline Turkey & $0.19^{\mathrm{a}}$ & $0.16^{\mathrm{a}}$ & 0.11 & 0.05 & 0.04 & 0.13 \\
\hline The UAE & 0.13 & 0.11 & 0.10 & 0.13 & 0.08 & $0.17^{\mathrm{a}}$ \\
\hline All countries & 0.11 & 0.10 & 0.13 & 0.02 & 0.04 & 0.02 \\
\hline
\end{tabular}

The results of the augmented Dickey-Fuller (ADF) unit root test (Dickey and Fuller, 1981) and the KPSS unit root test (Kwiatkowski et al., 1992) are reported. The results of $\mathrm{ADF}$, based on Akaike information criterion (AIC) with optimal lag length selected of $\mathrm{p}=2$ suggest the presence of nonstationarity for level data. However, the first differences were found to be stationary for all variables. The results of ADF test for unit root are interpolated by MacKinnon et al. (1999) approximate technique, and the critical values of ADF were $-3.455: 1 \% ;-2.877: 5 \% ;-2.570: 10 \%$ whereas, the superscript ' $a$ ' on figures in the table refers to critical values that are less than 5\% significance level. These results were confirmed by the results reported by KPSS test and so, for the level data, the results of KPSS suggest the presence of non-stationarity cases as the null that stationarity exists is rejected while it is deeply accepted for the first differences suggesting the presence of stationarity cases. As noted from the table and based on the Schwert criteria, a maximum lag length of 12 for KPSS test was selected and the critical values of KPSS test are as follows: 10\%: $0.119 ; 5 \%$ : 0.146; $2.5 \%$ : 0.176; $1 \%$ : 0.216 .

Table 2 presents the results of Johansen cointegration test through eigenvalue and trace test for the null hypothesis that there is no long run relationship between GDP per capita, $\mathrm{SO}_{2}$ and $\mathrm{CO}_{2}$. Since the selection of the optimal lags is important, when running this test, a likelihood ratio test was used for each series. A maximum of four lags was selected based on the $5 \%$ level of significance. We also considered the case of a linear trend. The results of Johansen's trace test suggest that the three variables were cointegrated for each country. It implies that there is a long-run relationship among these variables, 
and, therefore, there is evidence of a common stochastic trend. Our results also hold in the case of all countries as a panel. In the table, * denotes rejection of the null hypothesis at the 0.05 level whereas $* * *$ denotes a p-value less than $1 \%$ level, using MacKinnon et al. (1999) approximation.

Table 2. The results of Johansen cointegration test.

\begin{tabular}{|c|c|c|c|c|c|}
\hline & "Hypothesised No. of CE(s) & Eigenvalue & Statistics & (0.05 critical value & Prop**** \\
\hline \multicolumn{6}{|c|}{ Algeria } \\
\hline None $*$ & 0 & & 50.965 & 29.680 & 0.000 \\
\hline At most $1^{*}$ & 1 & 0.448 & 25.419 & 15.410 & 0.000 \\
\hline At most $2 *$ & 2 & 0.314 & 9.233 & 3.760 & 0.000 \\
\hline At most $3^{*}$ & 3 & 0.193 & & & \\
\hline \multicolumn{6}{|c|}{ Egypt } \\
\hline None * & 0 & . & 56.226 & 29.680 & 0.000 \\
\hline At most $1^{*}$ & 1 & 0.505 & 22.521 & 15.410 & 0.000 \\
\hline At most $2^{*}$ & 2 & 0.252 & 8.582 & 3.760 & 0.000 \\
\hline At most $3^{*}$ & 3 & 0.164 & & & \\
\hline \multicolumn{6}{|c|}{ Iran } \\
\hline None $*$ & 0 & . & 49.303 & 29.680 & 0.000 \\
\hline At most $1^{*}$ & 1 & 0.437 & 26.899 & 15.410 & 0.000 \\
\hline At most $2^{*}$ & 2 & 0.362 & 9.352 & 3.760 & 0.000 \\
\hline At most $3^{*}$ & 3 & 0.213 & & & \\
\hline \multicolumn{6}{|c|}{ Jordan } \\
\hline None $*$ & 0 &. & 38.455 & 29.680 & 0.000 \\
\hline At most $1^{*}$ & 1 & 0.353 & 25.464 & 15.410 & 0.000 \\
\hline At most $2^{*}$ & 2 & 0.229 & 6.331 & 3.760 & 0.000 \\
\hline At most $3^{*}$ & 3 & 0.034 & & & \\
\hline \multicolumn{6}{|c|}{ Kuwait } \\
\hline None $*$ & 0 & . & 57.572 & 29.680 & 0.000 \\
\hline At most $1^{*}$ & 1 & 0.535 & 25.427 & 15.410 & 0.000 \\
\hline At most $2^{*}$ & 2 & 0.311 & 9.783 & 3.760 & 0.000 \\
\hline At most $3^{*}$ & 3 & 0.208 & & & \\
\hline \multicolumn{6}{|c|}{ Morocco } \\
\hline None $*$ & 0 & . & 55.706 & 29.680 & 0.000 \\
\hline At most $1^{*}$ & 1 & 0.487 & 26.355 & 15.410 & 0.000 \\
\hline At most $2^{*}$ & 2 & 0.306 & 10.280 & 3.760 & 0.000 \\
\hline At most $3^{*}$ & 3 & 0.208 & & & \\
\hline \multicolumn{6}{|c|}{ Oman } \\
\hline None * & 0 & . & 62.112 & 29.680 & 0.000 \\
\hline At most $1^{*}$ & 1 & 0.508 & 34.444 & 15.410 & 0.000 \\
\hline At most $2^{*}$ & 2 & 0.414 & 13.612 & 3.760 & 0.000 \\
\hline At most $3^{*}$ & 3 & 0.295 & & & \\
\hline \multicolumn{6}{|c|}{ Qatar } \\
\hline None $*$ & 0 & & 38.891 & 29.680 & 0.000 \\
\hline At most $1^{*}$ & 1 & 0.462 & 17.830 & 15.410 & 0.000 \\
\hline At most 2* & 2 & 0.306 & 5.414 & 3.760 & 0.000 \\
\hline At most $3^{*}$ & 3 & 0.147 & & & \\
\hline \multicolumn{6}{|c|}{ Turkey } \\
\hline None $*$ & 0 & . & 66.238 & 29.680 & 0.000 \\
\hline At most $1^{*}$ & 1 & 0.536 & 32.415 & 15.410 & 0.000 \\
\hline At most $2^{*}$ & 2 & 0.350 & 13.428 & 3.760 & 0.000 \\
\hline At most $3^{*}$ & 3 & 0.263 & & & \\
\hline \multicolumn{6}{|c|}{ UAE } \\
\hline None $*$ & 0 & . & 55.315 & 29.680 & 0.000 \\
\hline At most $1^{*}$ & 1 & 0.950 & 16.250 & 15.410 & 0.000 \\
\hline At most $2^{*}$ & 2 & 0.522 & 6.648 & 3.760 & 0.000 \\
\hline At most $3^{*}$ & 3 & 0.400 & & & \\
\hline \multicolumn{6}{|c|}{ All countries } \\
\hline None $*$ & 0 & . & 83.95 & 29.68 & 0.000 \\
\hline At most $1^{*}$ & 1 & 0.065 & 33.66 & 15.41 & 0.000 \\
\hline At most $2^{*}$ & 2 & 0.024 & 15.36 & 3.76 & 0.000 \\
\hline At most $3^{*}$ & 3 & 0.020 & & & \\
\hline
\end{tabular}




\subsection{The relationship between economic development and $\mathrm{SO}_{2}$ and $\mathrm{CO}_{2}$ emissions}

Emissions of $\mathrm{SO}_{2}$ are among the most important forms of energy-related pollution problems. They are originated primarily from different industrial and power-generating sectors, and they are known for their adverse effects on human health and the natural environment. Table 3 shows the estimates of environmental Kuznets equations for $\mathrm{SO}_{2}$ in MENA countries. Since $\beta_{1}$ coefficients have significant positive impact on environmental degradation, and $\beta_{2}$ coefficients have a significant negative impact on environmental degradation there is an evidence for $\mathrm{SO}_{2}$ EKC for Algeria, Tunisia, Yemen, Morocco, Turkey and Libya. Our result correspond with Fodha and Zaghdoudi (2010) and Arouri et al. (2012b) on the evidence for Sulphur Dioxide EKC in Tunisia, but differs from Arouri et al. (2012b) on his inclusion of Egypt, which did not show EKC in our results.

Results also showed that $\beta_{1}$ and $\beta_{2}$ coefficients for Jordan, Israel and Egypt were within the expected signs, but only $\beta_{1}$ was statistically significant, which means that there is a monotonically increasing linear relationship between income and $\mathrm{CO}_{2}$ emissions. Countries like Saudi Arabia, Iran, the UAE and Iraq had the expected signs for their coefficients but without statistical significance for $\beta_{1}$ and $\beta_{2}$ together, which means that EKC evidence for them still does not exist. Also, there was no evidence for Kuznets curve in other countries like Mauritania, Syria, Qatar, Lebanon, Kuwait, Bahrain, Oman and Sudan since $\beta_{1}$ and $\beta_{2}$ coefficients did not show the expected signs.

Table 3. Estimates of environmental Kuznets equations for $\mathrm{SO}_{2}$ in MENA countries.

\begin{tabular}{|c|c|c|c|c|c|c|c|c|c|}
\hline \multirow{2}{*}{$\begin{array}{r}\text { Country } \\
\text { Algeria } \\
\end{array}$} & \multicolumn{2}{|c|}{$\mathbf{B}_{0}$} & \multicolumn{2}{|c|}{$\mathbf{B}_{1}$} & \multicolumn{2}{|c|}{$\mathbf{B}_{2}$} & \multirow{2}{*}{$\begin{array}{c}\begin{array}{c}\text { Turning point } \\
\text { (USD) }\end{array} \\
2440\end{array}$} & \multirow{2}{*}{$\begin{array}{c}\mathbf{R}^{\mathbf{2}} \\
0.76\end{array}$} & \multirow{2}{*}{$\begin{array}{c}\begin{array}{c}\text { Kuznets } \\
\text { Curve }\end{array} \\
\text { Yes }\end{array}$} \\
\hline & -118.0 & $(-4.2)^{* * *}$ & 31.2 & $(4.2) * * *$ & -2.0 & $(-4.0) * * *$ & & & \\
\hline Tunisia & -15.9 & $(-1.7)^{*}$ & 5.6 & $(2.2) * *$ & -0.36 & $(-2.1)^{* *}$ & 2387 & 0.99 & Yes \\
\hline Yemen & -12.5 & $(-8.0) * * *$ & 1.0 & $(7.9) * * *$ & -130.7 & $(-7.9) * * *$ & 518 & 0.83 & Yes \\
\hline Morocco- & -90.1 & $(-5.0) * * *$ & 24.0 & $(4.9) * * *$ & -1.6 & $(-4.4) * * *$ & 1808 & 0.96 & Yes \\
\hline Turkey & -152.0 & $(-3.8)^{* * *}$ & 34.2 & $(3.8) * * *$ & -2.0 & $(-3.6)^{* *}$ & 5,166 & 0.93 & Yes \\
\hline Libya & -40.1 & $(-4.2) * * *$ & 10.8 & $(4.7) * * *$ & -0.64 & $(-4.7) * * *$ & 4,616 & 0.39 & Yes \\
\hline Jordan & -22.5 & $(-1.7)^{*}$ & 6.2 & $(1.7)^{*}$ & -0.34 & $(-1.2)$ & - & 0.81 & No \\
\hline Israel & 29.3 & $(-1.9)^{*}$ & 6.3 & $(1.9)^{*}$ & -0.28 & $(-1.6)$ & - & 0.99 & $\mathrm{No}$ \\
\hline Egypt & -0.56 & $(-0.3)$ & 1.3 & $(2.2)^{* *}$ & -0.05 & $(-1.1)$ & - & 0.87 & No \\
\hline Saudi Arabia & -54.0 & $(-1.0)$ & 12.3 & $(1.2)$ & -0.60 & $(-1.1)$ & - & 0.98 & No \\
\hline Iran & -200.0 & $(-3.0) * * *$ & 53.5 & $(3.0)$ & -3.4 & $(-3.0)$ & - & 0.40 & No \\
\hline The UAE & -109.8 & $(-0.6)$ & 23.2 & $(0.68)$ & -1.2 & $(-0.73)$ & - & 0.73 & No \\
\hline Iraq & 1.8 & $(0.48)$ & 0.54 & $(0.48)$ & -0.01 & $(0.83)$ & - & 0.83 & No \\
\hline Mauritania & 161.7 & $(2.9)^{* * * *}$ & -45.9 & $(-2.9)^{* * *}$ & 3.3 & $(3.0) * * *$ & - & 0.78 & No \\
\hline Syria & 305.9 & $(3.4) * * *$ & -77.9 & $(-3.4) * * *$ & 5.0 & $(3.4) * * *$ & - & 0.60 & No \\
\hline Qatar & 13.3 & $(3.2) * * *$ & -2.4 & $(-2.7) * * *$ & 0.14 & $(2.9) * * *$ & - & 0.46 & No \\
\hline Lebanon & 148.8 & $(3.7) * * *$ & -37.2 & $(-3.8) * * *$ & 2.4 & $(4.0) * * *$ & - & 0.85 & No \\
\hline Kuwait & 20.9 & $(1.9)^{*}$ & -3.9 & $(-1.5)$ & 0.23 & $(1.8)^{*}$ & - & 0.47 & No \\
\hline Bahrain & 867.1 & $(0.5)$ & -190.4 & $(-0.52)$ & 10.5 & $(0.54)$ & - & 0.48 & No \\
\hline Oman & -12.1 & $(-1.0)$ & -0.15 & $(-0.05)$ & 0.22 & $(1.3)$ & - & 0.95 & No \\
\hline Sudan & 56.2 & $(1.7)^{*}$ & -17.3 & $(-1.5)$ & 1.4 & $(1.5)$ & - & 0.91 & No \\
\hline All countries & 3.6 & $(1.4)$ & 0.3 & $(0.44)$ & -0.02 & $(-0.47)$ & - & 0.87 & No \\
\hline
\end{tabular}

The last row in Table 3 shows overall regression results conducted for all MENA countries as a panel. Coefficients $\beta_{1}$ and $\beta_{2}$ were within the expected signs but without a statistical significance for both coefficients, meaning that EKC evidence for the whole region does not exist. Countries showing Kuznets curve evidence may have been effective in controlling the sources that are responsible for $\mathrm{SO}_{2}$ emissions and may have also relied on the enforcement of laws and the adoption of new technologies. They may have shifted to cleaner technology in matter of electricity generation, and they use more gas and less oil for power generation. This shift and more effective regulation lead to an improvement in the environmental quality. Olivier et al. (2005) reported that since the beginning of the 1970 s, more end-of-pipe technologies such as flue-gas desulphurisation have been adopted to filter $\mathrm{SO}_{2}$ emissions.

Our results show a large dispersion of turning points across different countries in the region. The results presented in Table 3 show that turning point for most MENA countries ranges from USD 518 in Yemen to USD 5,166 in Turkey. For example, the value of sulphur oxide emissions for Turkey begins to decrease when GDP per capita exceeds USD 5,166. This has occurred at the time interval between 1992 and 1993. On the contrary, when GDP per capita is less than USD 5,166 the values of sulphur oxide emissions increase with the rising GDP per capita. Previous studies, for example, Panayotou (1993), Grossman and Krugar (1995) and Shafik (1994) reported turning points for sulphur dioxide as USD 3,137, USD 4,053 and USD 4,379, respectively, which are more than those reported in our results for 
Algeria (USD 2,440), Tunisia (USD 2,387), Morocco (USD 1,808) and Yemen (USD 518).

Figure 2 shows the Kuznets curve for Algeria, Morocco, Turkey, Tunisia, Yemen and Libya. Countries like Yemen may have not had significant economic development throughout its history. Therefore, there were no intensive industrial and oil refining activities taking place on a big scale in this country, and this had intuitively led to less $\mathrm{SO}_{2}$ emissions. High income provinces in Turkey have used cleaner heating options such as natural gas and better quality coal, which caused air pollution to be less harmful (Akhbostanci et al., 2009). Arouri et al. (2012b) reported that, in Tunisia and since the end of the 1990s, pilot projects in the field of energy conservation encouraged the use of energy saving equipment in the housing sector, natural gas powered air conditioning in the services sector and natural gas as a fuel in the transport sector.

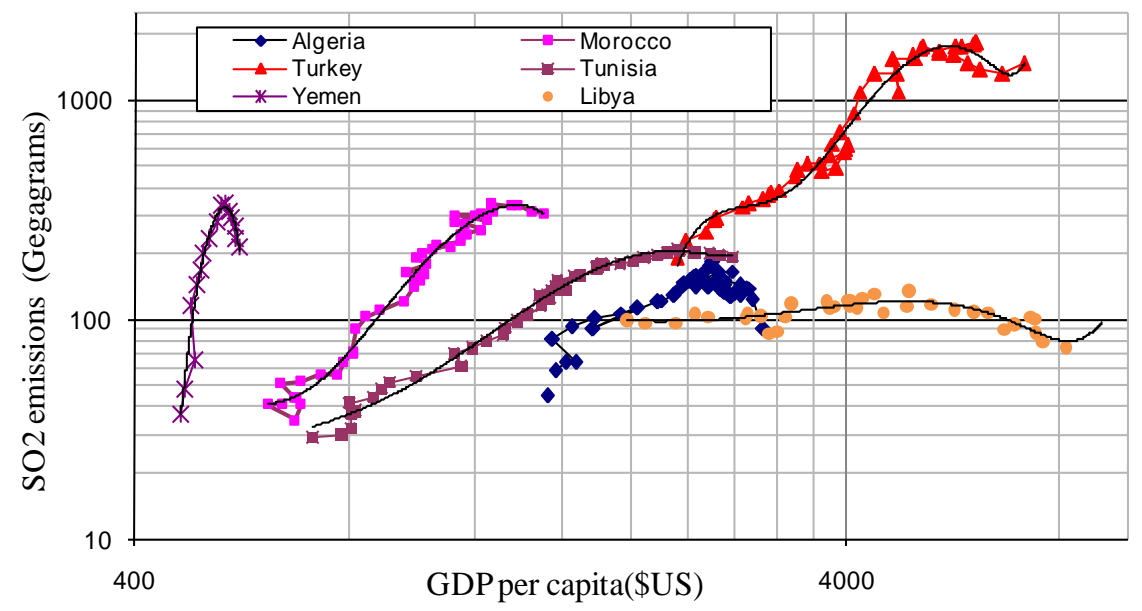

Figure 2. Environmental Kuznets curves for Algeria, Morocco, Turkey, Tunisia, Yemen, and Libya.

The rapid growth of energy demand especially for electricity generation in the absence of $\mathrm{SO}_{2}$ emission reduction technology may explain poor performances in matter of $\mathrm{SO}_{2}$ reduction in some other MENA countries such as Saudi Arabia, the UAE, Oman, Jordan, Mauritania, Sudan, Egypt and Syria. The region poses the challenge of addressing the air quality impacts associated with oil and gas exploitation, processing, reformulation and shipping as well as those resulted from expanding energyintensive industries such as power generation, petrochemicals, fertilizers, steel, aluminium, and cement sectors. Doukas et al. (2006) reported that gulf countries have shifted towards more energy efficient technologies and they are exploring new $\mathrm{SO}_{2}$ emission reduction policies. However, reorientation has not yet resulted in the development of consistent strategies and policies (Reiche, 2010). In addition, Arouri et al. (2012b) reported that when $\mathrm{SO}_{2}$ emissions do not decline as GDP per capita increases this can be explained by the spread of corruption. While laws in matter of air pollution exist, the enforcement of laws and control are ineffective due to corruption. The absence of change in matter of adoption of new technologies (end-of-pipe technologies) could also explain why most MENA countries were not successful in reducing their $\mathrm{SO}_{2}$ emissions level.

Based on International Energy Agency (IEA) classifications in 2013, the main sectors contributing to $\mathrm{CO}_{2}$ emissions in MENA region are energy sector (accounting for 46\%), transportation sector (accounting for 22\%), and industrial sector (accounting for 21\%). As a region, these values are similar to the world average and higher than those for Asia, excluding China and those for Latin America, excluding Mexico (International Energy Agency, 2012). Among MENA countries, Saudi Arabia has the highest share of $\mathrm{CO}_{2}$ emissions in regard to the energy sector, and Iran has the highest share of $\mathrm{CO}_{2}$ emissions in regard to the industrial and transportation sectors. Summary estimates of EKC equation for $\mathrm{CO}_{2}$ emissions in MENA countries are presented in Table 4. Taken together, our findings support an inverted U-shape pattern associated with the EKC hypothesis for Tunisia, Morocco, Turkey and Jordan, in which $\mathrm{CO}_{2}$ emissions increase with real GDP per capita, stabilise and then decrease. In contrast, Arouri et al. (2012a), who conducted his research on 12 MENA countries, found that only Jordan confirmed the EKC hypothesis.

Arouri et al. (2012a) reported that the decline of the $\mathrm{CO}_{2}$ emissions, as GDP increases, may be explained by more effectiveness of institutions and laws, the raise of citizens' awareness about climate change and moving towards more effective technologies in energy consuming sectors. For example, Al-Hiniti et al. (2007) reported that in a country like Jordan, which depends totally on imported fuel and suffers from worsening energy crises, the transportation sector is the largest energy consuming sector, and it is expected to grow faster than other sectors. Therefore, more attention has been directed towards the provision of feasible and effective options in this sector. 
Table 4. Summary estimates of environmental Kuznets equations for $\mathrm{CO}_{2}$ in MENA.

\begin{tabular}{|c|c|c|c|c|c|c|c|c|c|}
\hline Country & & $\mathbf{B}_{0}$ & & $\mathbf{B}_{1}$ & & $\mathbf{B}_{2}$ & $\begin{array}{l}\text { Turning point } \\
\text { (USD) }\end{array}$ & $\mathbf{R}^{2}$ & $\begin{array}{c}\text { Kuznets } \\
\text { curve }\end{array}$ \\
\hline Tunisia & -86.2 & $(-5.3)^{* * *}$ & 23.5 & $(5.6)^{* * *}$ & -1.5 & $(-5.3)^{* * *}$ & 2,523 & 0.97 & Yes \\
\hline Morocco- & -137.5 & $(-4.6) * * *$ & 38.0 & $(4.6) * * *$ & -2.6 & $(-4.4) * * *$ & 1,492 & 0.95 & Yes \\
\hline Turkey & -84.0 & $(-11.6)^{* * *}$ & 20.0 & $(11.5)^{* * *}$ & -1.2 & $(-10.3) * * *$ & 4,160 & 0.98 & Yes \\
\hline Jordan & -1.7 & $(-1.1)^{*}$ & 1.8 & $(3.7) * * *$ & -0.12 & $(-1.8)^{*}$ & 1,808 & 0.97 & Yes \\
\hline Iran & -143.9 & $(-1.6)$ & 38.7 & $(1.8)^{*}$ & -2.4 & $(-1.5)$ & - & 0.35 & No \\
\hline Djibouti & -282.0 & $(-1.5)$ & 84.6 & $(1.7)^{*}$ & -6.2 & $(-1.5)$ & - & 0.58 & No \\
\hline Oman & $-33 . .4$ & $(-2.2) * *$ & 6.2 & $(1.7)^{*}$ & -0.2 & $(-0.8)$ & - & 0.90 & No \\
\hline Saudi Arabia & -25.4 & $(-0.44)$ & 7.1 & $(0.6)$ & -0.33 & $(-0.55)$ & - & 0.97 & No \\
\hline Algeria & -64.7 & $(-1.1)$ & 15.3 & $(0.96)$ & -0.74 & $(-0.70)$ & - & 0.84 & No \\
\hline Syria & -30.0 & $(-1.1)$ & 8.3 & $(1.1)$ & -0.40 & $(-0.70)$ & - & 0.89 & No \\
\hline Bahrain & -96.5 & $(-0.4)$ & 20.6 & $(0.42)$ & -1.1 & $(-0.41)$ & - & 0.72 & No \\
\hline Lebanon & -16.3 & $(-0.53)$ & 3.3 & $(0.45)$ & -0.14 & $(-0.32)$ & - & 0.60 & No \\
\hline Libya & 73.0 & $(3.6)^{* * *}$ & -15.8 & $(-3.3) * * *$ & 1.0 & $(3.5) * * *$ & - & 0.49 & No \\
\hline Sudan & 60.4 & $(1.7)^{*}$ & -19.1 & $(-1.7)^{*}$ & 1.7 & $(1.9)^{*}$ & - & 0.84 & No \\
\hline Egypt & 12.8 & $(3.9) * * *$ & -2.7 & $(-2.8) * * *$ & 0.33 & $(2.1)^{* * *}$ & - & 0.98 & No \\
\hline Qatar & 20.6 & $(2.6)^{* *}$ & -3.0 & $(-2.0) * * *$ & 0.19 & $(2.3)^{* * *}$ & - & 0.54 & No \\
\hline Kuwait & 25.6 & $(3.17)^{* * *}$ & -4.0 & $(-2.3)^{* *}$ & 0.24 & $(2.6)^{* *}$ & - & 0.51 & No \\
\hline The UAE & 156 & $(1.9)^{*}$ & -26.2 & $(-1.7)^{*}$ & 1.2 & $(1.5)$ & - & 0.63 & No \\
\hline Israel & 7.3 & $(3.2)^{* * *}$ & -0.31 & $(-0.60)$ & 0.06 & $(1.8)^{*}$ & - & 0.94 & No \\
\hline Iraq & 11.9 & $(0.71)$ & -3.3 & $(-0.72)$ & 0.25 & $(0.83)$ & - & 0.54 & No \\
\hline Yemen & 328.2 & $(1.3)$ & -105.6 & $(-1.4)$ & 8.7 & $(1.4)$ & - & 0.86 & No \\
\hline Mauritania & 70.1 & $(0.50)$ & -20.3 & $(0.44)$ & 1.6 & $(0.44)$ & - & 0.91 & No \\
\hline All countries & -3.3 & $(-0.93)$ & 2.3 & $(2.6)^{* *}$ & -0.08 & $(-1.6)$ & - & 0.91 & No \\
\hline
\end{tabular}

*** Statistically significant at $1 \%$ level

** Statistically significant at 5\% level

* Statistically significant at $10 \%$ level

Figure 3 shows Kuznets curves for Morocco, Tunisia, Turkey and Jordan. The United Nations Environment Programme (2013) reported that national cleaner production centres have been established in some countries such as Morocco and Tunisia, and there has recently been increasing awareness of the diverse and complex results of air pollution. Public and private sectors establishments are becoming more interested in undertaking preventive measures to control air pollution, and there is a detectable shift from end-of-pipe treatments to a more proactive approach, including cleaner production and waste minimisation at source.

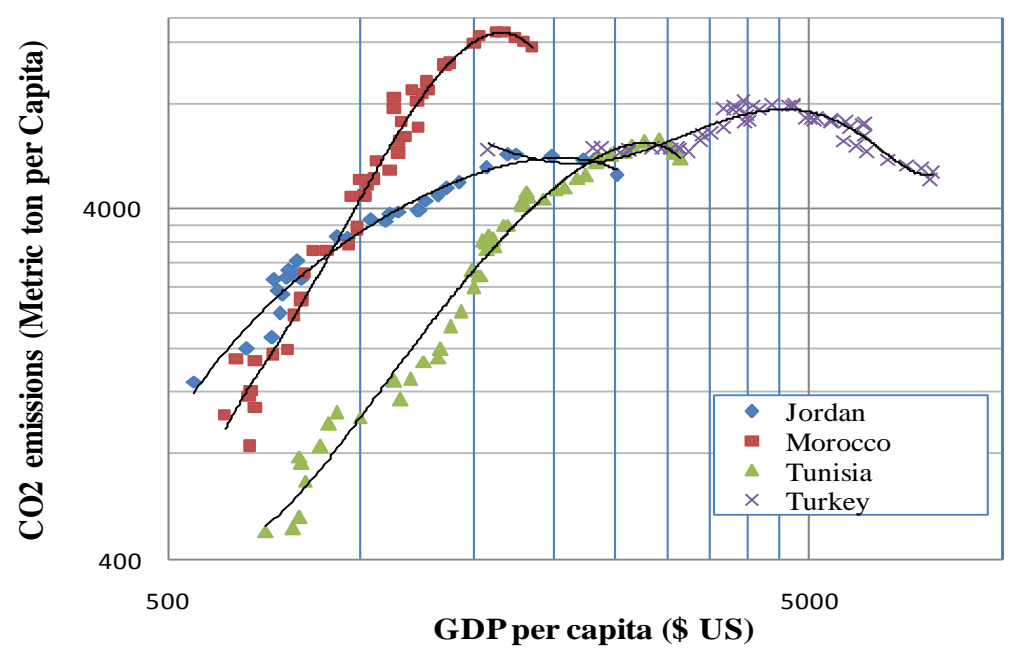

Figure 3. Environmental Kuznets curves for Morocco, Tunisia, Turkey and Jordan.

Industrial countries are more aware about the greenhouse effect and are using technology saving energy strategies in order to reduce the amount of $\mathrm{CO}_{2}$ emissions. By consequence, consumers in MENA countries are benefiting from this technological change. MENA countries like Jordan after a long period of subsidising oil in their domestic countries are moving towards a policy of 'the true prices' and are cutting these subsidies. As a consequence, there is a shift in the consumption of energy and the use of more energy saving and less polluting technologies. With regard to Turkey, Shahbaz et al. (2013) reported that Turkey is a candidate for full membership of the European Union (EU), and, therefore, it is likely to face significant pressure from the EU to introduce its 
national plan on climate change and global warming along with specific emissions targets.

Figure 3 shows that although Turkey has the highest turning point among other countries in the region, Tunisia, Morocco and Jordan, however, had experienced higher environmental degradation as GDP per capita increases compared to Turkey, which had experienced a slight increase. Optimal turning points of the EKC reported previously in Table 4 differ from one country to another, ranging from USD 1,492 for Morocco to USD 4,160 for Turkey. These differences could be attributed to the difference in economic structures, consumer pressure and environmental policies. Morocco, Jordan and Tunisia had turning points of USD 1,492, USD 1,808 and USD 2,523, respectively, which are less than those reported by previous studies such as Roberts and Grimes (1997) and Moomaw and Tullis (1997) that reported turning points of USD 8,000 and USD 12,800 , respectively.

The results also showed that $\beta_{1}$ and $\beta_{2}$ coefficients for Iran, Djibouti and Oman were within the expected signs, but only $\beta_{1}$ was statistically significant, which means that there is a monotonically increasing linear relationship between income and $\mathrm{CO}_{2}$ emissions. The coefficients of the countries like Saudi Arabia, Algeria, Syria, Bahrain and Lebanon were also within the expected signs, but $\left(\beta_{1}\right.$ and $\left.\beta_{2}\right)$ altogether were statistically insignificant, which means that there is still no inverted U-shaped curve presenting itself in the connection between the GDP per capita and $\mathrm{CO}_{2}$ emissions, and this emphasises the importance of policy decisions in determining environmental outcomes.

The rapid rise in $\mathrm{CO} 2$ emissions in Saudi Arabia is more likely to be related to its intensive industrial and civil development that took place after the discovery of oil and the need for electricity generation to supply continuous developments of domestic, tertiary and industrial establishments that continue to emerge until now (Qader, 2009). The rising of international oil demand, and the consequent increase in prices, is another factor for this rapid rise of $\mathrm{CO} 2$ emission in KSA.

Table 4 shows that Libya, Sudan, Egypt, Qatar, Kuwait, the UAE, Israel, Iraq, Yemen and Mauritania had no Kuznets curve evidence. This is because $\beta_{1}$ and $\beta_{2}$ coefficients for these countries had not shown the expected signs. Therefore, higher $\mathrm{CO}_{2}$ emissions occur from the economic growth due to intensive uses of energy (Lieb, 2003). As $\mathrm{CO}_{2}$ emissions have longterm effects, they are associated with relative high abatement cost and that discourage agents to undertake restrictive actions (Dinda, 2004). In the $\mathrm{UAE}$, for example, besides the influence of population growth, there is a significant amount of waste and over-consumption of energy, which adds to the insufficiency of the energy supply (Odhiambo, 2012).

Once regression is conducted for all countries (as a panel), results showed that $\beta_{1}$ and $\beta_{2}$ were within the expected signs, but only $\beta_{1}$ was statistically significant, which means that there is a monotonically increasing linear relationship between income and $\mathrm{CO}_{2}$ emissions. This result matches with other studies that found a linear relationship between $\mathrm{CO}_{2}$ emissions and per-capita GDP (Shafik and Bandyopadhyay, 1992; Roca et al., 2001; York et al., 2003).

MENA countries are among the world's top emitters of $\mathrm{CO}_{2}$ and $\mathrm{SO}_{2}$ in per capita terms, and the associated environmental problems are worsened through heavy subsidies on petroleum products, which encourage excessive and inefficient use of fossil energy. Eleven countries out of the total of 20 countries in the world which subsidised the gasoline consumption were from the MENA region (Brown, 2011). Oil refineries in MENA are the main sources of atmospheric pollution due to their emission of harmful gases, mainly hydrocarbons, carbons, nitrogen oxides and sulphur. Most of the plants there are not subjected to environmental evaluation prior to their establishment; therefore, they have adverse effects on the surrounding residential and maritime areas.

In order to reduce $\mathrm{SO}_{2}$ and $\mathrm{CO}_{2}$ emissions, the industrial plants are required to adopt the necessary pollution control systems and the necessary equipment and devices to limit or decrease the volume and concentration of these harmful pollutants.

\section{Conclusions}

The purpose of the paper was to examine whether or not the EKC relationship exists between economic growth and two environmental pollution indicators $\left(\mathrm{SO}_{2}\right.$ and $\left.\mathrm{CO}_{2}\right)$ based on a country level analysis using time series data for all of the 22 MENA countries in the region. Under a country level, there is an evidence of $\mathrm{SO}_{2}-$ EKC for Algeria, Tunisia, Yemen, Morocco, Turkey and Libya. Our findings for $\mathrm{CO}_{2}$ emissions also support an inverted U-shape pattern associated with the EKC hypothesis for Tunisia, Morocco, Turkey and Jordan. In analysing MENA region as a panel, our results showed that there is no $\mathrm{EKC}$ evidence for $\mathrm{SO}_{2}$ and $\mathrm{CO}_{2}$ emissions, but there is only a monotonically increasing linear relationship between income and $\mathrm{CO}_{2}$ emissions.

This study stresses the need for environmental policy in MENA region and it gives a prescription for policy makers in order to alleviate some of the forms of environmental degradation in the region. Countries which did not show EKC evidence in each of the two environmental pollutants are required to foster economic growth because there is ample empirical evidence that confirms that environmental quality increases with the level of income, and so policy has a very important role to play by promoting both sustained growth and the environment. Increasing knowledge of the impacts of environmental degradation, stricter policy measures as well as demanding for the enforcement and adoption of best environmental practices are all required for countries which are inconsistent with EKC hypothesis. 
For countries which showed EKC evidence, promoting economic growth through increasing investments or liberalisation of international trade cannot be the only panacea to reduce environmental problems. Therefore, it is essential that these countries would keep on promoting clean technical progress and preservation activities in order to permanently address the economy along a sustainable falling arm of EKC in which an increase in income is accompanied by a decrease in pollution.

In order to reduce environmental degradation in the whole region and since most $\mathrm{CO}_{2}$ and $\mathrm{SO}_{2}$ emissions are emitted through industrial activities, the region is encouraged to upgrade its production system by reconstructing cleaner techniques and equipment, process control and cleaner products. It also has to utilise cleaner energy resources and an alternative use of harmful materials.

\section{References}

Al-Hiniti, I, Al-Ghandoor, A, Akash, B and Abu-Nada, E. (2007) Energy saving and CO2 mitigation through restructuring Jordan's transportation sector: The diesel passenger cars scenario. Energy Policy 35(10): 50035011. doi: http://dx.doi.org/10.1016/j.enpol.2007.04. 024.

Al-mulali, U. (2012) Factors affecting CO2 emission in the Middle East: A panel data analysis. Energy, 44(1): 564569. doi: http://dx.doi.org/10.1016/j.energy.2012.05. 045 .

Alstine, J and Neumayer, E. (2010) The environmental Kuznets curve. In: Gallagher, Kevin P. (Ed.) Handbook on trade and the environment (pp. 49-59). Cheltenham, UK: Edward Elgar Publishing (ISBN 9781847204547).

Arouri, M, Yousef, A, Mhenni, H, Rault, C. (2012a) Energy Consumption, Economic Growth and $\mathrm{CO} 2$ Emissions in Middle East and North African Countries. Energy Policy 45: 342-349. doi: http://dx.doi.org/10.1016/ j.enpol.2012.02.042.

Arouri, M, Yousef, A, Mhenni, H, Rault, C. (2012b) Empirical Analysis of the EKC Hypothesis for Sulfur Dioxide Emissions in Selected Middle East and North African Countries. Journal of Energy and Development 37(1,2): 207-226.

Brown, L. (2011) World on the Edge: How to Prevent Environmental and Economic Collapse. New York, USA: W. W. Norton and Company.

British Petroleum (2014). Statistical review of world energy 2014. Available at: http://www.bp.com/en/global/ corporate/about-bp/energy-economics/statistical-reviewof-world-energy.html (accessed 23/7/2014).

Dickey, D. A., and Fuller, W. A. (1981) Likelihood ratio statistics for autoregressive time series with a unit root. Econometrica 49(4): 1057-72. doi: http://dx.doi.org/ $10.2307 / 1912517$.

Dinda, S. (2004) Environmental Kuznets Curve Hypothesis: A Survey, Ecological Economics 49(4): 431- 455. doi: http://dx.doi.org/10.1016/j.ecolecon.2004.02.011.

Djoundrian, S. (2011) Environmental movement in the Arab World. Environment, Development and Sustainability 13(13): 743-758. doi: http://dx.doi.org/10.1007/s10668011-9287-7.

Doukas, H, Patlitzianas, K.D., Kagiannas, A.G., Psarras, J. (2006) Renewable energy sources and rationale use of energy development in the countries of GCC: Myth and reality? Renewable Energy 31(6): 755-770. doi: http://dx.doi.org/10.1016/j.renene.2005.05.010.

Energy Information Administration (2014). International Energy Statistics. Available at: http://www.eia.gov/ cfapps/ipdbproject/iedindex3.cfm?tid=90\&pid=45\&aid $=8 \&$ cid $=\&$ syid $=2004 \&$ eyid $=2010 \&$ unit $=$ MTCDPP (accessed 21/7/2014).

Farzanegan, M, Markwardt, G. (2012). Pollution, Economic Development and Democracy: Evidence from the MENA countries (Working Paper). Centre for European Economic Research, Technische Universität Dresden, Dresden, Germany. Available at: http://works.bepress.com/mr_farzanegan/14 (accessed 25/7/2014).

Fodha, M, Zaghdoud, O. (2010) Economic growth and pollutant emissions in Tunisia: An empirical analysis of the environmental Kuznets curve. Energy Policy 38(2): 1150-1156. doi: http://dx.doi.org/10.1016/j.enpol. 2009.11.002.

Gurluk, S. (2009) Economic growth, industrial pollution and human development in the Mediterranean Region. Ecological Economics 68(8-9): 2327-2335. doi: http://dx.doi.org/10.1016/j.ecolecon.2009.03.001.

Grossman, G, Krueger, A. (1995) Economic growth and the environment. Quarterly Journal of Economics 110(2): 353-78. doi: http://dx.doi.org/10.2307/2118443.

International Monetary Fund (2011). The next five years MENA PE. Available at: http://campuses.insead.edu/ abu_dhabi/research/documents/INSEAD-MENA-PEReport-2011.pdf (accessed 15/7/2014).

International Energy Agency (2012). Statistics. Available at: http://www.iea.org/ (accessed 27/4/2013).

International Energy Agency (2013). International Environmental Agreements Database Project (Version 2013.1). Available at: http://iea.uoregon.edu/ (accessed 25/72014).

Jaunky, V. (2010) The CO2 Emissions-Income Nexus: Evidence from Rich Countries. Energy Policy 39(3): 1228-1240. doi: http://dx.doi.org/10.1016/j.enpol. 2010.11.050.

Johansen, S. (1998) Statistical Analysis of Cointegrating Vectors. Journal of Economic Dynamics and Control, 12(2-3): 231-254. doi: http://dx.doi.org/10.1016/01651889(88)90041-3.

Kraft, J., Kraft, A. (1978) On the relationship between energy and GNP. Journal of Energy and Development 3(2): 401-403.

Kwiatkowski, D, Phillips, P, Schmidt, P, Shin, Y. (1992) Testing the null hypothesis of stationary against the alternative of a unit root: how sure are we that economic time series have a unit root? Journal of Econometrics 54(1-3): 159-178. doi: http://dx.doi.org/10.1016/03044076(92)90104-Y.

Lieb, C M. (2003).The Environmental Kuznets Curve - A survey of the empirical evidence and of possible causes (Discussion Paper Series No 391). University of Heidelberg, Department of Economics. Available at: http://www.uni-heidelberg.de/md/awi/forschung/ dp391.pdf (accessed 21/2/2014).

Moomaw, M., Unruh, G. (1997) Are environmental Kuznets curves misleading us? The case of $\mathrm{CO} 2$ emissions. Environmental and Development Economics 2(4): 45163. doi: http://dx.doi.org/10.1017/S1355770X97000247.

Narayan, P, Narayan, S. (2010) Carbon dioxide emissions and economic growth: panel data evidence from developing countries. Energy Policy 38(1): 661-666. doi: http://dx.doi.org/10.1016/j.enpol.2009.09.005.

Odhiambo, G. (2012) Energy Consumption and Carbon Emission in the UAE. In: International Conference on Life Science and Engineering. Available at: 
http://www.ipcbee.com/vol45/001-ICLSE2012D003.pdf (accessed 15/2/2014).

Olivier, J, Aadenne, J, Dentener, F, Pagliari, V, Ganzeveld, L, Peters, J. (2005) Recent Trends in Global Greenhouse Gas Emissions: Regional Trends 1970 2000 and Spatial Distribution of Key Sources in 2000. Environmental Science 2(2-3): 81-99. doi: http://dx.doi.org/10.1080/15693430500400345.

Orubu, C, Omotor, D. (2011) Environmental quality and economic growth: Searching for environmental Kuznets curves for air and water pollutants in Africa. Energy Policy 39(7): 4178-4188. doi: http://dx.doi.org/ 10.1016/j.enpol.2011.04.025.

Oxford Dictionary (2013). Definition. Available at: http://oxforddictionaries.com/definition/english/policy? q=policy (accessed 21/1/2014).

Panayotou, T. (1993). Empirical tests and policy analysis of environmental degradation at different stages of economic development (Working Paper). International Labor Office, Technology and Employment Programme, Geneva.

Qader, M. (2009) Electricity Consumption and GHG Emissions in GCC Countries. Energies 2(4): 1201-1213. doi: http://dx.doi.org/10.3390/en20401201.

Reiche, D. (2010) Energy Policies of Gulf Cooperation Council (GCC) countries-possibilities and limitations of ecological modernization in rentier states. Energy Policy 38(5): 2395-2403. doi: http://dx.doi.org/10.1016/ j.enpol.2009.12.031.

Roca, J., Padilla, E., Farré, M., Galletto, V. (2001) Economic growth and atmospheric pollution in Spain: discussion the environmental Kuznets hypothesis. Ecological Economics 39(1): 85-99. doi: http://dx.doi.org/10.1016/S0921-8009(01)00195-1.

Roberts, J. and Grimes, P. (1997) Carbon intensity and economic development 1962-91: A brief exploration of the environmental Kuznets curve, World Development 25(2): 191-8. doi: http://dx.doi.org/10.1016/S0305750X(96)00104-0.

Shafik N., Bandyopadhyay S. (1992) Economic growth and environmental quality: Time series and cross country evidence (Policy Research Working Paper No WPS904). Available at: http://wwwwds.worldbank.org/external/default/WDSContentServer /IW3P/IB/1992/06/01/000009265_3961003013329/Ren dered/PDF/multi_page.pdf (accessed 25/2/2014).

Shafik N. (1994) Economic development and environmental quality: an econometric analysis, Oxford Economics Papers 46(0): 757-73.

Shahbaz, M. Ozturk, L, Afza, T and Ali, A. (2013) Revisiting the environmental Kuznets curve in a global economy. Renewable and Sustainable Energy Reviews 25: 494-502. doi: http://dx.doi.org/10.1016/j.rser. 2013.05.021.

Soytas, U, Sari, R, Ewing, T. (2007) Energy consumption, income, and carbon emissions in the United States. Ecological Economics 62(10): 482-489. doi: http://dx.doi.org/10.1016/j.ecolecon.2006.07.009.

Soytas, U, Sari, R. (2009) Energy consumption, economic growth, and carbon emissions: challenges faced by an EU candidate member. Ecological Economics 68(6): 1667-1675. doi: http://dx.doi.org/10.1016/j.ecolecon. 2007.06.014.

United Nation Environmental Program (2013). Africa environment outlook. Available at: http://www.unep.org/DEWA/Africa/docs/en/AEO2_Our _Environ_Our_Wealth.pdf (accessed 15/6/2014).

US Geological Survey (2013). Commodity statistics and information. Available at: http://minerals.usgs.gov/ minerals/pubs/commodity (accessed 25/7/2014).
World Bank (2014). World Bank Data. Available at: http://data.worldbank.org/ (accessed 25/72014).

York, R, Rosa, E.A., Dietz, T. (2003) STIRPAT, IPAT and ImPACT: analytic tools for unpacking the driving forces of environmental impacts. Ecological Economics 46(3): 351-365. doi: http://dx.doi.org/10.1016/S09218009(03)00188-5. 


\title{
Oro tarša ir ekonomikos augimas Artimuosiuose Rytuose ir Šiaurès Afrikoje: AKK hipotezės patikrinimas
}

\author{
Rami Al-Rawashdeh ${ }^{1}$, Aiman Q. Jaradat ${ }^{1}$, Mohammad Al-Shboul ${ }^{2}$ \\ ${ }^{1}$ Inžinerijos koledžas, Al-Hussein Bin Talal universitetas, Manas, Jordanija \\ ${ }^{2}$ Finansu ir ekonomikos departamentas, Verslo administravimo koledžas, Sharjah universitetas, JAE
}

\begin{abstract}
Aplinkos Kuznetso kreivès (AKK) hipoteze yra vienas iš modelių, kuriuo aprašomas ekonomikos augimo ir aplinkos kokybès ryšys. Šio tyrimo tikslas buvo ištirti sasają tarp ekonomikos augimo ir dviejų aplinkos apsaugos rodikliu (išmetamo $\mathrm{SO}_{2}$ ir $\mathrm{CO}_{2}$ kiekio) 22-ose Artimujų Rytų ir Šiaurès Afrikos (MENA) šalyse. Remiantis analize šalies lygiu ir naudojant laiko eilutes tyrimu parodyta, kad vertinant išmetamą $\mathrm{SO}_{2}$ kieki $\mathrm{AKK}$ hipotezė galiojo Alžyre, Tunise, Jemene, Maroke, Turkijoje ir Libijoje. Išmetamo $\mathrm{CO}_{2}$ kiekio vertinimu taip pat patvirtintas su AKK hipoteze susijęs apverstos „U“ raidès formos modelis Tunise, Maroke, Turkijoje ir Jordanijoje. Rezultatai taip pat parode, kad, vertinant išmetamą $\mathrm{SO}_{2}$ ir $\mathrm{CO}_{2}$ kiekị MENA regionui, kaip vienetui, AKK hipotezė negaliojo. Griežtesnès politinès priemonès ir aukštesni geriausios patirties aplinkos apsaugos srityje perèmimo reikalavimai yra būtini siekiant gauti apverstos „U“ raidès formos kreivès sąsają tarp BVP vienam gyventojui ir aplinkos būklès prastėjimo.

Raktiniai žodžiai: Kuznetso kreive, MENA, ekonomikos augimas, tarša, aplinka.
\end{abstract}

